\title{
PROSPECTS OF SARS-CoV-2 VACCINES AND THEIR LANDSCAPE
}

\author{
Bharti Kotarya $^{1}$ (D), Abhishek Pandeya ${ }^{1}$ (D) Raj Kumar Khalko $^{1}$ (D), Anup Mishra ${ }^{1}$ (D), \\ Arti Priyadarshini ${ }^{1}$ (D) N. Vijaya ${ }^{2}$ (D), Manoj Kumar $\operatorname{Singh}^{3}$ (D), \\ Sudipta Saha ${ }^{4}$ (D), Sunil Babu Gosipatala ${ }^{1 *}$ (iD)
}

\footnotetext{
${ }^{1}$ Department of Biotechnology, School of Life Sciences, Babasaheb Bhimrao Ambedkar University, Lucknow-226025, Uttar Pradesh, India.

${ }^{2}$ Department of Mathematics, Koneru Lakshmaiah Education Foundation, Vaddeswaram, Guntur, Andhra Pradesh -522502, India

${ }^{3}$ Department of Mathematics and Statistics', Banasthali Vidyapith, Vanasthali, Rajasthan- 304022, India

${ }^{4}$ Department of Pharmaceutical Sciences, Babasaheb Bhimrao Ambedkar University, Lucknow-226025, Uttar Pradesh, India.
}

Received - October 01, 2020; Revision - November 05, 2020; Accepted - November 15, 2020

Available Online November 30, 2020

DOI: http://dx.doi.org/10.18006/2020.8(Spl-1-SARS-CoV-2).S246.S263

KEYWORDS
COVID-19 vaccines
DNA
RNA
Viral vector
Subunit Vaccines
Vaccine production strategies

\begin{abstract}
Severe Acute Respiratory Syndrome Corona Virus -2 (SARS-CoV-2), puzzled the whole world with its diverse, unique clinical spectrum, and unprecedented transmission dynamics. The disease caused by this virus is named as Coronavirus disease-19 (COVID-19), reported first time in Wuhan, China, in December 2019. It had spread to almost all countries of the world disrupting the health and economy of many countries. It was the recent zoonotic spillover disease reported in humans from the Coronavirus group, without proper medicine and non-existence of prior immunity, this disease posed a challenge to both the scientific and medical fraternity. The search for safe, effective drugs to treat the disease and vaccines against the causative agent SARS- CoV-2 had begun all over the world with public and private partnerships. Many countries are part of the solidarity trail for identifying the effective drugs, clinical trials and vaccines for this global pandemic. Here in this review, we are focussing on the different vaccine production platforms being used in the preparation of vaccines against SARS-CoV-2, their current status and prospects. Vaccine production technology significantly advanced in recent times by imbibing the cutting edge technologies such as nucleic acid based technologies such as DNA/RNA/Codon deoptimization and availability of safe and effective viral vectors produced through rDNA technology. The availability of complete genome sequence of SARS-CoV-2, geared up for the production of vaccine
\end{abstract}

* Corresponding author

E-mail: sunil_gos@yahoo.com (Dr. Sunil Babu Gosipatala)

Peer review under responsibility of Journal of Experimental Biology and Agricultural Sciences.

Production and Hosting by Horizon Publisher India [HPI] (http://www.horizonpublisherindia.in/).

All rights reserved.
All the articles published by Journal of Experimental Biology and Agricultural Sciences are licensed under a Creative Commons Attribution-NonCommercial 4.0 International License Based on a work at www.jebas.org.

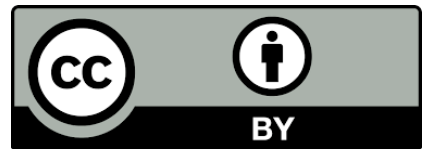


candidates based on these new vaccine production platforms, and in a record time of 4-5 months, these vaccine candidates entered in human clinical trials for the evaluation of safety and efficacy. Prior knowledge on SARS and MERS-CoV's structural and genomic features, vaccine production platforms used in making vaccines against them greatly augmented in the SARS-CoV-2 vaccine efforts. As per World Health Organization (WHO) a total of 202 vaccine candidates are under developing for SARS-CoV-2, among them 47 entered in clinical trials and 156 are in the preclinical stage. These vaccines are prepared by an amalgamation of both new and old traditional vaccine production platforms such as nucleic acid base platforms, inactivated, live attenuated, recombinant viral vectors, protein and peptide-based vaccines. The success of these vaccine candidates lies in the generation of effective immune response for SARS-CoV-2 across all age groups and people with co-morbidities. We briefly summarize the different strategies of SARS-CoV-2 vaccine production and their prospects with an emphasis on different routes of administration and added a basic mathematical model depicting the importance of vaccination for any pandemic.

\section{Introduction}

The causative agent of coronavirus disease 2019 (COVID-19), Severe Acute Respiratory Syndrome Corona Virus-2 (SARS$\mathrm{CoV}-2$ ), grappled the whole world with its high transmission rate and unprecedented etiology. It severely affected human health and wealth in recent times of $21^{\text {st }}$ century than any disease or natural calamity (Dhama et al., 2020a; Rodriguez-Morales et al., 2020). SARS-CoV-2 belongs to the beta Coronavirus family and their natural reservoirs are bats. Coronaviruses are known to cross the species barriers to cause infections in humans. The SARS-CoV-2 is such $7^{\text {th }}$ coronavirus that crossed the species barrier and causing infections in humans (Dhama et al., 2020b; Tiwari et al., 2020). It was first reported in Wuhan, Hubei province, China in December 2019. It contains a single strand, positive-sense RNA as genome of 30000 nucleotides. The etiology of the disease caused by this virus is getting unraveled by the Scientists. It exhibits lesser case fatality rate (CFR) when compared to the earlier Corona viral outbreaks such as SARS-2002 and MERS 2012 (Liu et al., 2020), however, its high transmission rate caused wreck havoc. The mortality caused by this disease has been reported to be associated with age and people with co-morbidities, wherein severe outcome of the disease occurs with higher mortality rates (Arumugam et al., 2020; Michelozzi et al., 2020). Till date, with no specific drug, most of the countries are treating this disease with the repurposing of the drugs and containing the viral spread through maintaining the social distancing and following hygienic practices. Researchers across the globe are making high efforts to develop effective vaccines and drugs against COVID-19, few of which are in pipeline and are being tested at different phases of clinical trials (Rabaan et al., 2020a; Rabaan et al., 2020b; Yatoo et al., 2020). At the time of this review $\left(6^{\text {th }} \mathrm{Nov} 2020\right)$, more than 1.2 million deaths occurred worldwide due to COVID-19, and more than 46 million were infected with this disease.

Vaccines proved to be a safe bet in tackling the epidemics, though they were not 100 percent safe and effective. Since, the first recorded use of immunization in humans to prevent smallpox by Edward Jenner 1796, the development and scope of vaccines have seen incremental progress (Riedel, 2005). With the advent of technologies, the field of vaccine production has been benefitted and the latest production platforms such as DNA and RNA vaccines, non-replicating viral vector vaccines, recombinant protein vaccines, and cell-culture based vaccines became available (Wallis et al., 2019) and all these strategies have been employed in preparing the vaccines against SARS-CoV-2 (Callaway et al., 2020; Yatoo et al., 2020; Rabaan et al., 2020b).

The genome sequencing studies of SARS $-\mathrm{CoV}-2$ resulted not only in understanding the genomic variability, evolution but also paved a way for the vaccines based on the nucleic acid, reverse genetics vaccine production platforms. The genetic and structural studies related to SARS, MERS, and SARS CoV-2, resulted in accelerating the different vaccine candidates against SARS-CoV-2. Many labs around the world are working tirelessly in making effective vaccines in controlling the COVID-19 pandemic. Most of the vaccine candidates are based on the envelop protein "Spike" (Zhu et al., 2020; Lauxmann et al., 2020; Tai et al., 2020), as the studies show it was able to elicit both the $\mathrm{T}$ and $\mathrm{B}$ cell immune response. The studies on SARS -CoV's revealed the functional importance of surface glycoprotein named "Spike" (S)" protein and its role in viral attachment to the cellular receptor Angiotensin converting enzyme-2 (ACE2). The "S" protein containing S1 and S2 regions, separated with unique "furin" cleavage expressed on the viral envelope in defined number and expressed as trimeric form (Walls et al., 2020; Cai et al., 2020). The "S" protein plays an important role in cell attachment and further, the protease priming the "S" protein promotes the fusion of virion with the target cell (Lan et at., 2020). The SARS-CoV-2 virion structure and the detailed structure of Spike protein, i.e., trimeric form, its sub units "S1" and "S2" with furin cleavage and the laying down and standing confirmations are shown in figure 1. The structural details of "S" protein is a good candidate to target the SARS $\mathrm{CoV}-2$ as the earlier studies with the antibodies raised against this 

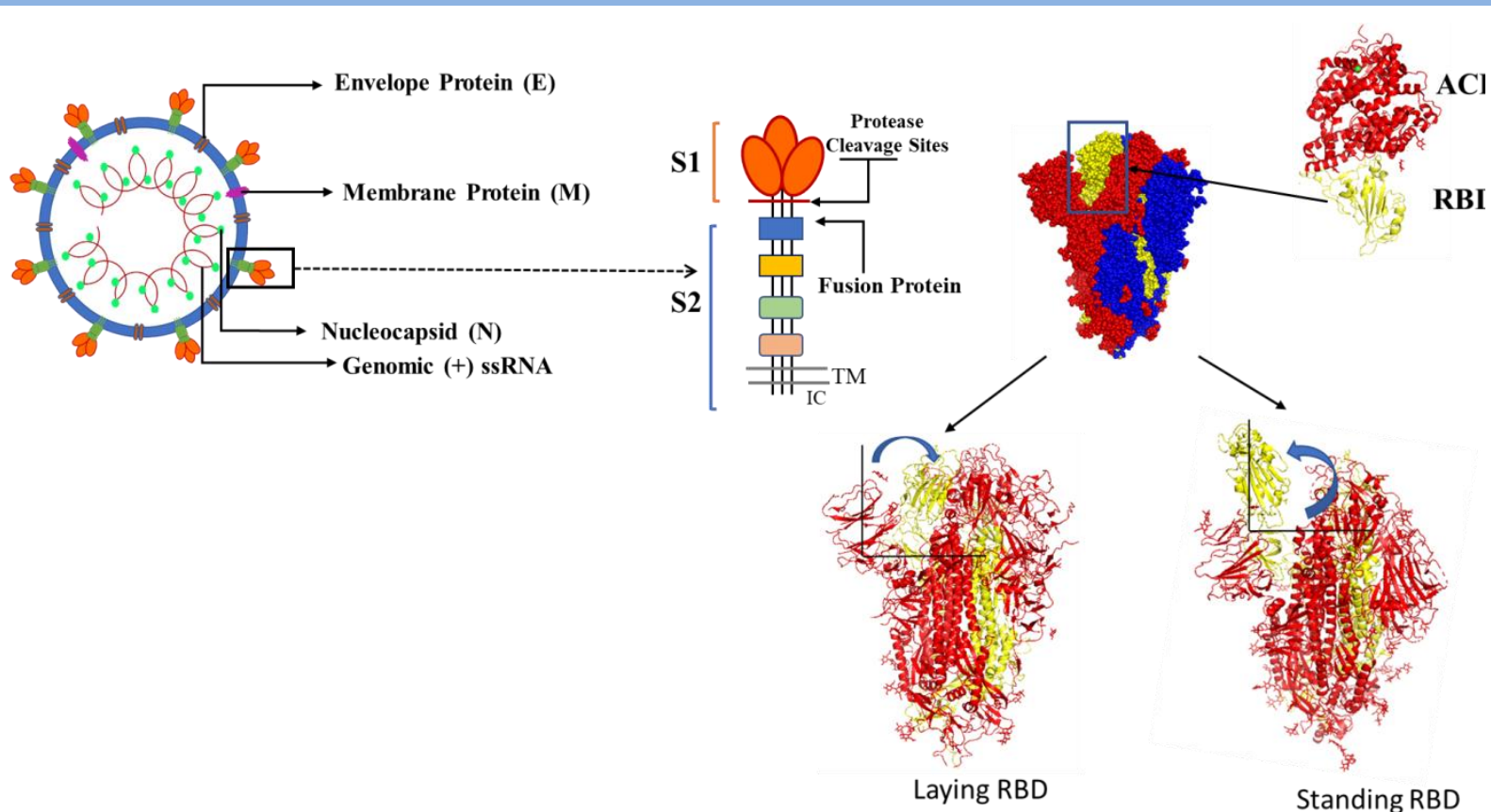

Figure 1 Structure of SARS-CoV-2 virion, Spike protein in trimeric form and its sub units with furincleavage ; the standing and laying confirmations of RBD region of spike protein (The general structural features of SARS-CoV-2 virion detailing the envelop proteins and the nuclear material. The detailed subunits of Spike protein (S1/S2) with furin cleavage. The trimeric form of Spike protein, the standing and laying confirmations of RBD region of Spike protein is also shown (Source: ACE with RBD- PDB ID: 6M0J; ACE- PDB ID: 6XM5; Laying RBD- PDB ID: 6ZP7; Standing RBD- PDB ID: 6VXX.).

protein show sufficient neutralizing activities (Salvatori et al., 2020). Most of the vaccines are exploiting this protein fully or partially and its confirmations are used in making the vaccines, using any platform of vaccine production. For, example the prefusion and fusion confirmation of "S" protein, either whole "S" protein or only the standing receptor binding region (RBD) (amino acids from 318-510 of spike protein) confirmation of "S" protein used in making the peptide vaccines. The " $\mathbf{S}$ " protein before binding to the cell posses closed confirmation only, however, while going to bind with the cellular receptor, one of the RBD region of the trimeric form changes its confirmation to laying down to standing position (Shang et al., 2020; Song et al., 2020).

\section{Key considerations in SARS-CoV-2 vaccine development}

For a successful vaccine candidate for SARS-CoV-2, it is required to be safe in all individuals including the most susceptible COVID19 individuals such as elderly people, people with co-morbidities, immunocompromised individuals and children. Special attention to be given to these segments of the people, because of immune senescence, older people respond less to vaccination, so this can be overcome by the specific formulations which include more antigen or an adjuvant (DiazGranados et al., 2013; Calina et al., 2020). Another observation reported in the COVID-19 is the waning of antibody response in the SARS-CoV-2 infected individuals after some time (Lan et al., 2020). If the protective immune response is disappearing in few weeks, it can't be an effective vaccine candidate. This makes them get reinfected with the SARS- CoV-2, giving the concept that the human coronaviruses do not always induce long-lived antibody response. Further, the vaccine developed should not subject to geographic and temporal variability, and also standardize the antigen with the adjuvant and route of administration without overt reactogenicity.

\section{Vaccine production platforms for SARS- CoV-2}

As the race for producing the vaccine for COVID-19 began, different vaccine production platforms are being explored, of them some are relatively new and some are traditional. The different vaccine production platforms and the stage of development were shown in Figure 2a \& b. Presently, no DNA or RNA based vaccine(s) are available for any disease, however, these production approaches are being explored for SARS-CoV-2 vaccines. According to the World Health Organization (WHO), currently $\left(6^{\text {th }}\right.$ November 2020), 47candidate vaccines for COVID-19 are in the clinical phase $1 / 2 / 3$, while 155 are in the preclinical phase. The front runners include RNA/DNA based vaccines, which utilized the leverage of the nucleic acid sequences and made quickly. The SARS-CoV-2 vaccines entered in clinical trials by the different vaccines production platforms are tabulated in Table 1. 
(A)

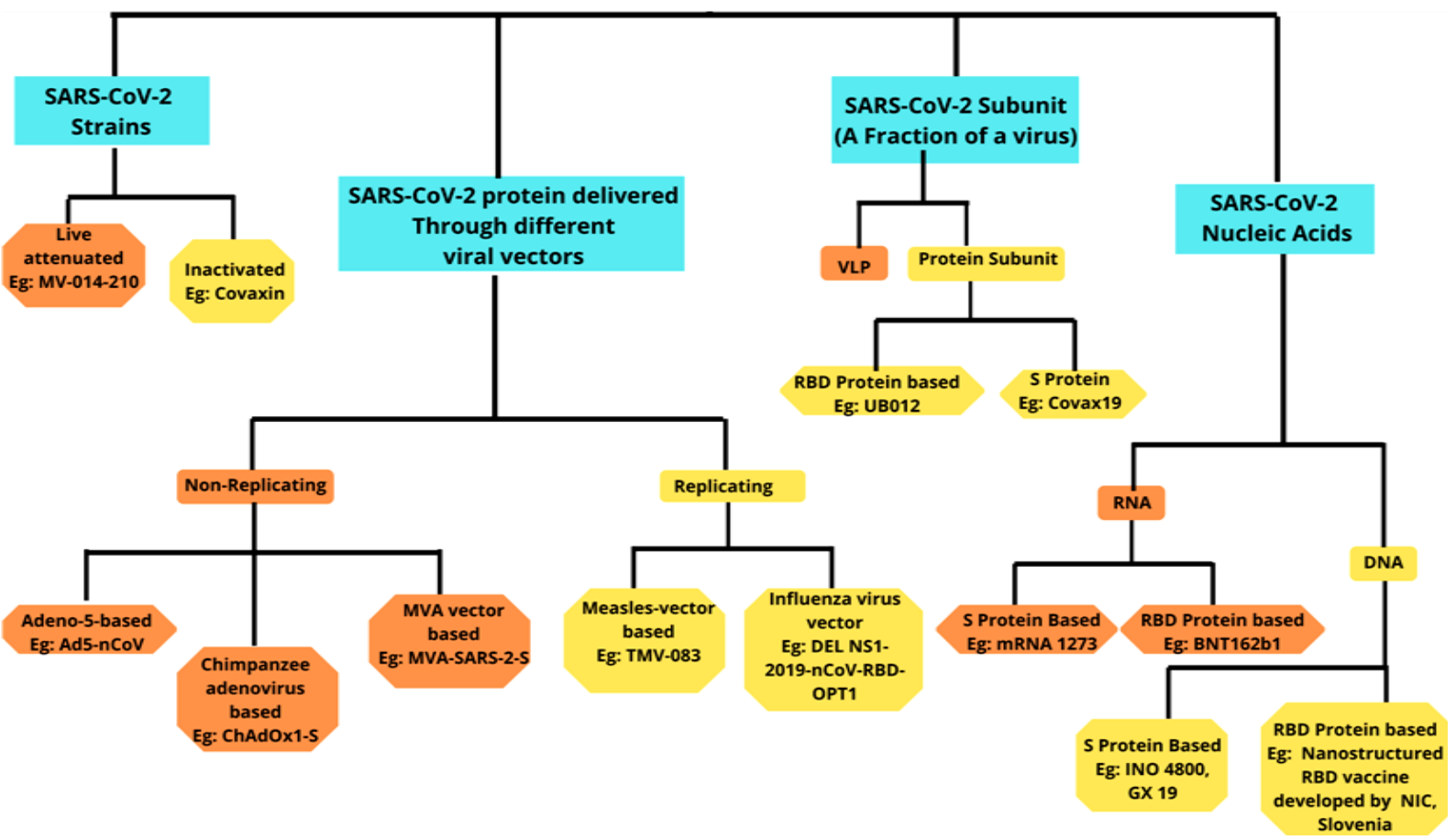

(B)

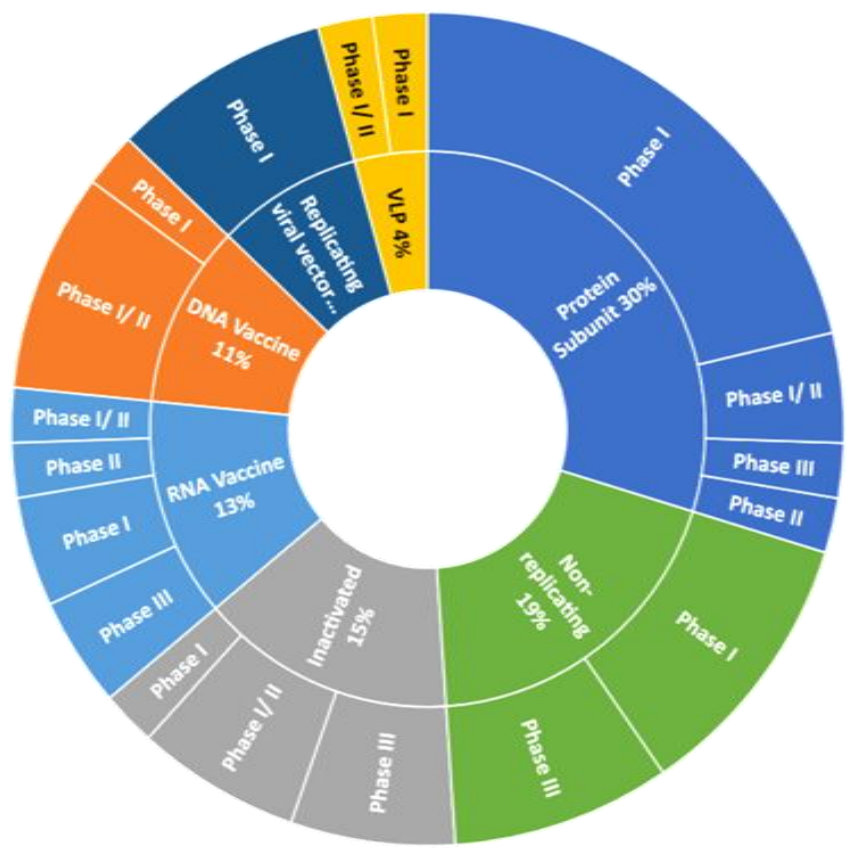

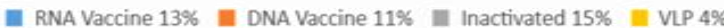

- Protein Subunit 30\%

Replicating viral vector $8 \%$

Figure 2 (a) Different vaccine production platforms employed for SARS- CoV-2 Vaccines (Different vaccine production platforms used in the preparation of SARS-CoV-2 vaccines) and (b) their current status (Pie Chart showing the current status of the vaccines in Clinical trials)

Journal of Experimental Biology and Agricultural Sciences http://www.jebas.org 
Table1 Different Vaccine production platforms for SARS-CoV-2 Vaccines, name of the manufacturers and their respective phases of Clinical trials

\begin{tabular}{|c|c|c|c|c|}
\hline $\mathbf{S}$ & Vaccine & Developer & $\begin{array}{l}\text { Type of candidate vaccine/ } \\
\text { description }\end{array}$ & $\begin{array}{l}\text { Current } \\
\text { status }\end{array}$ \\
\hline \multicolumn{5}{|c|}{ (A) Plat form: RNA based } \\
\hline 1 & ARCOV & PLA Academy of Military Sciences/Walvax Biotech & mRNA & Phase 1 \\
\hline 2 & $\mathrm{CVnCoV}$ & Curevac & mRNA & Phase 2 \\
\hline 3 & LNP-nCoVsaRNA & Imperial College London/ Vacequity Global Health & self- amplifying RNA vaccine & Phase 1 \\
\hline 4 & ARCT-021 & Arcturus Therapeuics, Inc. & mRNA & Phase 3 \\
\hline 5 & $\begin{array}{l}\text { BNT162 (BNT162b1 \& } \\
\text { BNT162b2) }\end{array}$ & BioNTech/Pfizer/ Fosun Pharma & 3 LNP-MRNAS & Phase 3 \\
\hline 6 & mRNA 1273 & Moderna/ NIAID/ Rovi/ Catalent/ Bioqual/Medidata & LNP-Encapsulated mRNA & Phase 3 \\
\hline \multicolumn{5}{|c|}{ (B) Plat form: DNA based } \\
\hline 1 & GX-19 & Genexine consortium & $\begin{array}{l}\text { DNA vaccine expressing "S" } \\
\text { protein }\end{array}$ & Phase $1 / 2$ \\
\hline 2 & AG0301- COVID 19 & $\begin{array}{l}\text { Takara Bio in collaboration with Osaka University and } \\
\text { AnGes Inc }\end{array}$ & $\begin{array}{l}\text { DNA plasmid } \\
\text { (administered with adjuvant) }\end{array}$ & Phase $1 / 2$ \\
\hline 3 & INO- 4800 & $\begin{array}{l}\text { Inovio pharmaceuticals/ International vaccine institute } \\
\text { in association with Coalition for epidemic preparedness } \\
\text { Innovation (CEPI). }\end{array}$ & $\begin{array}{l}\text { Plasmid vaccine with } \\
\text { electroporation }\end{array}$ & Phase $1 / 2$ \\
\hline 4 & ZyCoV-D & Zydus Cadila Healthcare Ltd. & DNA plasmid & Phase $1 / 2$ \\
\hline 5 & bacTRLSpike & Symvivo & $\begin{array}{l}\text { DNA plasmid containing S } \\
\text { protein coding synthetic DNA, } \\
\text { orally delivered vaccine }\end{array}$ & Phase 1 \\
\hline \multicolumn{5}{|c|}{ (C) Plat form: Non-replicating Viral vectors } \\
\hline 1 & ChAdOx1-S & $\begin{array}{l}\text { The University of Oxford in collaboration with pharma } \\
\text { company AstraZeneca }\end{array}$ & $\begin{array}{l}\text { Non-replicating chimpanzee } \\
\text { adenovirus-based }\end{array}$ & Phase 3 \\
\hline 2 & No name & Cansino Biologics & $\begin{array}{l}\text { Adenovirus type } 5 \text { vector ( AD5- } \\
\text { NCoV) }\end{array}$ & Phase 3 \\
\hline 3 & $\begin{array}{l}\text { Gam-COVID-VAC } \\
\text { LYO }\end{array}$ & Gamaleya Research Institute & Adeno-based & Phase 3 \\
\hline 4 & Ad26COV2S1 & $\begin{array}{l}\text { Janssen Pharmaceuticals/Biological E/ Beth Israel } \\
\text { Deaconess medical center/Catalent/Emergent } \\
\text { Biosloluton }\end{array}$ & $\begin{array}{l}\text { Ad26-vector-based vaccine } \\
\text { encoding a prefusion stabilized S } \\
\text { Protein }\end{array}$ & Phase 3 \\
\hline 5 & $\begin{array}{l}\text { Recombinant Ad5- } \\
\text { nCoV }\end{array}$ & Institute of biotechnology/ AMMC/PLA of China & Adeno5- based & Phase 1 \\
\hline 6 & MVA-SARS-2-S & Ludwig-Maximilians- University of Munich & $\begin{array}{l}\text { S protein expressing Modified } \\
\text { Vaccinia Virus Ankara }\end{array}$ & Phase 1 \\
\hline 7 & No name & Vaxart/Emergent BioSolutions & Oral vaccine platform & Phase 1 \\
\hline 8 & No name & Reithera/ Leukocare/ Univercells & $\begin{array}{l}\text { Replication defective simian } \\
\text { Adenovirus ( GRAD) }\end{array}$ & Phase 1 \\
\hline 9 & hAd5-SFusion+NETSD & Immunity Bio/ NantKwest Inc. & $\begin{array}{l}\text { Had5 vector with E1/E2b/E3 } \\
\text { deletion exressig spike fusion } \\
\text { pprotein and nucleocapsid along } \\
\text { with domain of enhanced T-cell } \\
\text { stimulation }\end{array}$ & Phase 1 \\
\hline \multicolumn{5}{|c|}{ (D) Platform: Replicating Viral Vectors } \\
\hline 1 & TMV-083 & $\begin{array}{l}\text { Institute Pasteur/ Themis/ University of Pittsburgh/ } \\
\text { MERCK }\end{array}$ & Measles vector (V591) & Phase 1 \\
\hline 2 & No name & $\begin{array}{l}\text { Xiamen University/ Beijing Wantai Biological } \\
\text { Pharmacy }\end{array}$ & Flu-based-RBD (intranasal) & Phase 1 \\
\hline 3 & No name & $\begin{array}{l}\text { Israel Institute for biological Research/ Weizmann Inst. } \\
\text { Of science }\end{array}$ & vsv-s & Phase 1 \\
\hline 4 & V590 & Merck sharp \& Dohme/IAVII & Deliver S protein of SARS-CoV2 & Phase 1 \\
\hline
\end{tabular}

Journal of Experimental Biology and Agricultural Sciences

http://www.jebas.org 


\begin{tabular}{|c|c|c|c|c|}
\hline $\begin{array}{l}\mathrm{S} . \\
\mathrm{N}\end{array}$ & Vaccine & Developer & $\begin{array}{l}\text { Type of candidate vaccine/ } \\
\text { description }\end{array}$ & $\begin{array}{l}\text { Current } \\
\text { status }\end{array}$ \\
\hline \multicolumn{5}{|c|}{ (E) Plat form: Protein Sub Unit Based } \\
\hline 1 & No name & $\begin{array}{l}\text { AZLB/ Institute of microbiology, Chinese academy of } \\
\text { sciences }\end{array}$ & $\begin{array}{l}\text { Adjuvanted recombinant protein } \\
\text { (RBD-dimer) }\end{array}$ & Phase 2 \\
\hline 2 & $\begin{array}{l}\text { UQ-1-SARS-CoV-2- } \\
\text { Sclamp }\end{array}$ & University of Queensland/ Seqirus & $\begin{array}{l}\text { Molecular clamp stabilized S } \\
\text { protein with MF59 adjuvant }\end{array}$ & Phase 1 \\
\hline 3 & NVX-COV2373 & $\begin{array}{l}\text { Novavax/Serum Institute of India/ Emergent } \\
\text { Biosolutions/ Praha Vaccines/AGC Biologics/ SK } \\
\text { Biosciences/ Fujifilm Diosynth }\end{array}$ & $\begin{array}{l}\text { Full length recombinant SARS- } \\
\text { CoV-2 glycoprotein nanoparticle } \\
\text { vaccine adjuvanted with matrix M }\end{array}$ & Phase 3 \\
\hline 4 & SCB-2019 & Clover Biopharmaceuticals, vaccine & $\begin{array}{l}\text { Native like trimeric subunit } S \\
\text { protein }\end{array}$ & Phase 1 \\
\hline 5 & Covax- 19 & $\begin{array}{l}\text { Vaxine Pty Ltd/Medytox/Flinders University/ Oracle/ } \\
\text { Syparma }\end{array}$ & $\begin{array}{l}\text { Recombinant spike } \\
\text { proteinwithadvax adjuvant }\end{array}$ & Phase 1 \\
\hline 6 & No name & Kentucky bioprocessing & RBD based & Phase $1 / 2$ \\
\hline 7 & No name & Medigen vaccine/ Biologics corp/NIAID/ Dynavax & S2 protein + CPG 1018 & Phase 1 \\
\hline 8 & No name & Sanofi Pasteur & S protein, baculovirus production & Phase $1 / 2$ \\
\hline 9 & No name & Institute Finlay de vacunes, Cuba & RBD & Phase 1 \\
\hline 10 & No name & West China Hospital, Sichuan University & RBD based & Phase 1 \\
\hline 11 & No name & University Hospital Tuebingen & SARS-CoV-2 HLA-DR peptides & Phase 1 \\
\hline 12 & UB-612 & COVAXX & RBD based & Phase 1 \\
\hline 13 & No name & FBRI SRC VB vector, Rospotrebnadzor Koltsovo & Peptide vaccine & Phase 1 \\
\hline 14 & No name & Instituto Finlay de vacunes, Cuba & $\begin{array}{l}\text { Recombinant RBD which is } \\
\text { reduced in CHOcell and chemically } \\
\text { conjugate to tetanus toxoid }\end{array}$ & Phase 1 \\
\hline \multicolumn{5}{|c|}{ (F) Plat form: Whole Virus Inactivated } \\
\hline 1 & Covaxin & $\begin{array}{l}\text { Bharat Biotech/ ICMR/ National institute of Virology, } \\
\text { India }\end{array}$ & Whole virion inactivated & Phase 3 \\
\hline 2 & No name & $\begin{array}{l}\text { Institute of Medical Biology, Chinese Academy of } \\
\text { Medical Sciences, China }\end{array}$ & Inactivated & Phase 2 \\
\hline 3 & $\begin{array}{l}\text { Absorbed COVID- } \\
\text { 19inactivated Vaccine }\end{array}$ & Sinovac, & Inactivated +alum & Phase 3 \\
\hline 4 & No name & Beijing Institute of Biological Products/ Sinopharm & Inactivated vaccine (Vero cells) & Phase 3 \\
\hline 5 & No name & Wuhan Institute of Biological Products/ Sinopharm & $\begin{array}{l}\text { Inactivated novel coronavirus } \\
\text { pneumonia vaccine (Vero cells) }\end{array}$ & Phase 3 \\
\hline 6 & No name & $\begin{array}{l}\text { Research institute for Biological safety problems, } \\
\text { Republic of Kazakhstan }\end{array}$ & Inactivated & Phase $1 / 2$ \\
\hline 7 & No name & Beijing Minhai Biotechnology Co. Ltd. & Inactivated & Phase 1 \\
\hline \multicolumn{5}{|c|}{ (G) Plat form: Live attenuated Virus } \\
\hline 1 & No name & $\begin{array}{l}\text { Mehmet Ali Aydinlar university/Scibademlabmed } \\
\text { health service A.S. }\end{array}$ & $\begin{array}{l}\text { Codon deoptimized live attenuated } \\
\text { vaccines }\end{array}$ & Preclinical \\
\hline 2 & No name & Indian immunologicals Ltd/ Griffith University & $\begin{array}{l}\text { Codon deoptimized live attenuated } \\
\text { vaccines }\end{array}$ & Preclinical \\
\hline 3 & No name & Codagenix/Serum institute of India & $\begin{array}{l}\text { Codon deoptimized live attenuated } \\
\text { vaccines }\end{array}$ & Preclinical \\
\hline 4 & MV-014-210 & Meissa vaccines & MV-114-210 & Preclinical \\
\hline \multicolumn{5}{|c|}{ (H) Plat form: Viral like particle vectors } \\
\hline 1 & No name & Medicago Inc. & $\begin{array}{l}\text { Plant derived VLP adjuvanted with } \\
\text { Gsk or Dynavax Adjs. }\end{array}$ & Phase 1 \\
\hline 2 & No name & SpyBiotech/ Serum Institute of India & $\begin{array}{l}\text { RBD SARS-CoV-2 Hepatitis B } \\
\text { surface Ag }\end{array}$ & Phase $1 / 2$ \\
\hline
\end{tabular}

(A) RNA based vaccines and their present status. (B) DNA based vaccines and their present status (C) Non-replicating Viral Vectors based vaccines and their present status. (D) Replicating viral vector-based vaccines and their present status. (E) Protein Sub Unit based vaccines and their present status(F) Whole Virus inactivated vaccines and their present status (G) Live attenuated viral particle-based vaccines and their present status. (H) Viral like particle Vector (VLP) based vaccines and their present status. 


\subsection{RNA vaccines}

The potential of messenger Ribonucleic acids (mRNA's) as prophylactic vaccine were explored and few of them were tested for their suitability in different infectious diseases including respiratory diseases. Many Biotech companies are using mRNA platform based COVID-19 vaccines, such as Moderna, USA; BioNTech, Germany; Translate Bio with Sanofi US and, Fosum Pharma, Shanghai, China. Among them, Moderna, USA in association with National Institute for Allergy and infectious diseases (NIAID), Vaccine Research Center, NIH was in front runner position, and its vaccine mRNA1273 entered into phase III clinical trials and be given as intramuscular. This vaccine was found to be effective in the age groups tested i.e., 18-71 years. It was formulated by using mRNA of "Spike" protein of SARSCoV-2 having the transmembrane region, containing "S1" and "S2" subunits with furin cleavage stabilised as prefusion confirmation as 2 proline substitutions at $\mathrm{S} 1$ subunit at positions 986 and 987 (S-2p) in nanolipid formulation (Corbett et al., 2020 Rego et al., 2020; Jackson et al., 2020). Another mRNA based vaccine designated as BNT162 b1\&2, developed jointly by BioNTech (Germany) and Pfizer. The vaccine preparation includes the modified nucleoside RNAs of RBD antigen (BNT162b1) and whole "spike" protein (BNT162b2) of SARSCoV-2. They encapsulated a single nucleoside modified mRNAs in a nanolipid formulation and administered to the individuals. The effective immune generation was observed in BNT162b2 and the companies are started phase III clinical trials of spike is make use of fatty nanoparticles cover the mRNAs of proteins of SARSCoV-2 (Khuroo et al., 2020)

\subsubsection{Advantages}

These vaccines are easy to construct, directly from the desired pathogen genetic sequence. No risk of integration in the host genome.

\subsubsection{Concerns}

Despite advantages, there are some challenges such as, the short half-life of mRNA, transfection efficacy, which is around ten-fold lower than viral vector and lower protein translation. These are toxicity because of the intrinsic inflammatory activity, these vaccines are fragile thus requires an uninterrupted cold chain for transport and storage (Conforti et al., 2020; Wang et al., 2020)

\subsection{DNA vaccines}

In this vaccine production platform, the genetically engineered DNA molecules are used as vaccine candidates. These DNA's upon entering into the body, encode antigen(s) against which both the humoral and cellular immune response builts. Currently 15 vaccine candidates are being developed based on this vaccine production platform for COVID-19, from which 5entered in the clinical trials and the rest are in the preclinical phase. INO- 4800, is the first DNA vaccine that went into humans trials in April 2020, developed by Inovio pharmaceuticals/ International vaccine institute in association with Coalition for epidemic preparedness Innovation (CEPI). This is a plasmid DNA containing the sequence of spike protein of SARS-CoV-2 (Smith et al., 2020; Accor. to the Drugbank). In animal models, this vaccine generated immune response against Spike protein and the antibodies raised were able to block the SARS CoV-2 attachment to the cells (Smith et al., 2020). It was is administered by using handheld device (CELLECTRA) to create temporary pores in the cells near the injection site by delivering electrical pulses (King, 2020) and reported be stable at room temperature for more than one year which does not even need to be frozen in transport (Carlson, 2020).

Another DNA-based vaccine, GX-19 developed by Genexine Consortium comprising Binex, GenNBio, International Vaccine Institute, Pohang University of Science, and Technology, and Korea Advanced Institute of Sciences and Technology entered phase $1 / 2$ clinical trials (Khan, 2020).

Tahara Bio in collaboration with Osaka University and AnGes Inc. and Cadila Healthcare Ltd. have also developed plasmid DNA vaccine: AG0301-COVID-19 (with adjuvants) and ZyCoV-D vaccine (India's second COVID-19 vaccine) respectively which are in phase 1/2 clinical trials. Bac TRLSpike DNA based vaccine is the first in human: the study of bacTRLSpike and use of orally delivered bacTRL, developed by Symvivoand entered in phase I clinical evaluation. 14 other vaccines based on DNA platform are in pre-clinical phase.

\subsubsection{Advantages}

They offer several advantages such as good biocompatibility, long shelf life and stability, as manufacturing is completely cell free thus bypassing the need for BSL2 and making its large scale production process easy, cost-effective, and fast (Hobernik \& Bros, 2018; Koirala et al., 2020).

\subsubsection{Concerns}

The possibility of DNA integration in the host genome and the low generation of the immune response. Some studies show that the vaccine DNA has remained as a extra chormosomal in the muscle tissues (Wolff et al.,1992; Manam et al., 2000; Al-Kassmy et al., 2020).

\subsection{Non-replicating viral vector vaccines}

The vaccine production platform was greatly improved in the recent past and has efficient viral vectors such as Adenoviral vectors system and Ankara Viral system etc. The replicating deficient Adenoviral vectors developed from the Adenoviral 
serotypes from 1-5, the protocols were standardized and well established. The University of Oxford in collaboration with pharma company AstraZeneca developed a non-replicating Simian Adenoviral vector (ChAdOx-1) containing full length "Spike" protein of SARS- CoV-2 with a tissue plasminogen activator leader sequence and called as AZD1222 vaccine (Shi et al., 2020a). This vaccine is in phase III clinical trials and being testing in all age groups. The Can Sino Biological in collaboration with the Beijing Institute of Biotechnology using the Adenoviral vector system developed for COVID-19 vaccine Ad5-nCV.The vaccine contains the spike protein sequences from the Wuhan-Hu-1 strain of SARS- CoV-2, inserted in the Ad5 based vector with tissue plasminogen activator as a promoter (E1\&E3 deleted Ad5 vector). This vaccine was reported to induce both antibody and CD8+ T cell responses to SARS- CoV-2.

The University of Wiscosin-Madison has also developed a nonreplicating viral vector based vaccine by using self-limiting version of influenza virus M2SR which lacks M2 gene and modified by inserting Spike protein sequence known as Coroflu vaccine in collaboration with Flugen and Bharat biotech , this vaccine administered intra-nasally (Rauch et al., 2018; Kaur \& Gupta, 2020)

\subsubsection{Advantages}

The vaccines based on this production platform has several advantages such as they are safe, stable, accommodate large genes, doesn't require a cold chain facility, administered oral as well as intranasal, high transfection efficacy with no risk of integration in the host genome (Ertl, 2016; Markusic et al., 2017; Afrough et al., 2019; Wang et al., 2020). Both the adenoviral/ Vaccinia viralbased vectors are being used in gene therapy for many years.

\subsubsection{Concerns}

Requirement of high doses for eliciting the strong immune response (Guroff, 2007).

\subsection{Protein Subunit Vaccines}

Protein subunit vaccines are produced by purifying the proteins of the pathogen or by using recombinant DNA technology (Vetter et al., 2018). For SARS-CoV-2, more than 40 protein subunit-based vaccines are currently in the clinical/ preclinical phases (Funk et al., 2020), and are mostly based on the "Spike" protein (Shi et al., 2020b). SARS$\mathrm{CoV}-2$ rs is such a recombinant "S" protein nanoparticle vaccine mixed with Matrix M adjuvant and is currently in phase 2 clinical trials developed by Novavax, USA. University of Queensland/CSL/Seqirus, USA and Vaxine Pty Ltd, Australia/Medy Tox South Korea, developed a sub-unit vaccine, named UQ-1-SARS-CoV-2-Sclamp (spike protein which is stabilized by molecular clamp) and Covax-19 (recombinant "S" protein with adjuvant- Advax-SM) respectively, and these are currently in phase1 trials (Infovac, 2020; Jefferys, 2020;
$\mathrm{NIH})$. Many companies have developed spike protein receptor binding region (RBD) based vaccines, viz., Anhui ZhifeiLongcom Biopharmaceuticals/ Institute of Microbiology, Kentucky Bioprocessing Inc, USA, and they are in phase II clinical trials. British American Tobacco developed KBP- COVID-19 RBD-based vaccine that is developing by using the technology of fast-growing tobacco plants is entered in phase $1 / 2$ (Crop biotech update, 2020). Plant-based vaccine production system is being exploited to provide effective and safer COVID-19 vaccines (Dhama et al., 2020d).

\subsubsection{Advantages}

They have come with advantages such as safe- as they contain recombinant protein that is non-infectious, developed through "reverse genetics" approach, easy to produce, ability to combine many pathogen epitopes in a single vaccine, without the requirement of the cold chain (Strugnell et al., 2011).

\subsubsection{Concerns}

However, they have some limitations also particularly the poor immunogenicity: requirement of multiple dosages with adjuvants (Afrough et al.,2019; Wang et al., 2020).

\subsection{Whole virus inactivated or killed}

In this vaccine platform, the whole virus is inactivated through heat or chemical treatments and is one of the traditional plat form of vaccine production. This platform is also explored to prepare a vaccine against COVID-19 and the Covaxin (BBV152) developed by Bharat Biotech India Limited (BBIL) in association with National Institute of Virology, Pune, with Indian Council Medical Research, New Delhi, India, is an example for such type of vaccine. This vaccine is prepared by the SARS- CoV-2 strain isolated from the asymptomatic individual in India (Murugan, 2020), and it entered phase III clinical trials. There are total of 7 vaccine candidates developed for SARS CoV-2 on this platform are in clinical phase and 4 of them had entered in phase 3 clinical trials, one produced by Bharat Biotech; one by Sinovac Biotech, China; one by Wuhan Institute of Biological products/ Sinopharm; and one by the Beijing Institute of Biological Products prepared by inactivating SARS-CoV-2 that has been grown in VERO cell line. The vaccine was tested in the age groups ranging from 3-59 years; all the four vaccine candidates are found to be Immunogenic.

\subsubsection{Advantages}

This vaccine production strategy has been using for many years as a successful vaccination platform.

\subsubsection{Concerns}

The main limitations of the vaccines produced in this platform are that these couldn't cause infection in the body thereby unable to 
achieve the full spectrum of the adaptive immune response (Afrough et al., 2019), which leads to short and limited vaccination response. Further, the people involved in doing the inactivation process may have the risk of infection and the purification is not fully achieved the proteins with another protein agglutinates may cause affect the immunogenicity (Francis, 2017).

\subsection{Live attenuated vaccines ( $\mathrm{LAV})$ vaccines}

Live attenuation platform is explored for SARS-CoV-2 vaccine by adopting reverse genetics mechanism via deleting the key virulence factors (E protein deletion or inactivation of NSP14's exonuclease effects). The SARS CoV2 vaccine based on this platform ("E" protein has been attenuated), increased $\mathrm{CD} 4^{+}$and $\mathrm{CD} 8^{+} \mathrm{T}$ cell counts, and reduction in lung injury associated proinflammatory cytokines has been reported (Al-Kassmy et al., 2020; Dhama et al., 2020c). Currently, Codon deoptimization technology is used in producing such type of vaccines and is currently in the preclinical stage. Codagenix/ Serum Institute of India (CDX005), Mehmet Ali Aydinlar University, and Indian immunologicals Ltd/ Griffith University have developed such live attenuated vaccines. Another option for COVID-19 vaccine might be a chicken CoV known as IBV (Infectious bronchitis virus, strain $H$ ) live attenuated vaccine, as it was suggested to be useful for SARS (Dhama et al., 2020c).

\subsubsection{Advantages}

Vaccines based on this platform (LAV) are found to employ wide cross- protection, these are immunologically highly efficient and it can be scale -up for mass production.

\subsubsection{Concerns}

The major disadvantages of LAV that during distribution, cold chain should be maintained and require extensive safety testing because there is a risk that it can revert to full virulence(Francis, 2017; Shin et al., 2020; Amanat \& Krammer, 2020; Begum et al., 2020; Frederiksen et al.,2020).

\subsection{Virus-like particle (VLP) based Vaccines}

The vaccine developed by this technology can mimic the native virus (formed by self-assembly of the capsid protein of the virus); can't replicate as it doesn't have genetic material. Vaccines developed on this technology for COVID-19, mimic the conformation of SARS$\mathrm{CoV}-2$ virion, can generate a strong immune response without the need of adjuvant. Medicago Inc, is developing the vaccine on this platform for SARS-CoV-2, and testing with adjuvant (AS03 or CpG 1018) and without adjuvants (Infovac, 2020), is in clinical phase 1 trial (study started on 10 July 2020) and will be given as intramuscular to the people of 18-55 years of age (NIH). Another vaccine based on this platform developed by Serum Institute of India/ Spy Biotech i.e., RBD SARS-CoV-2 Hepatitis B surface Ag VLP vaccine (RBD-HBsAg
VLPs), entered in phase $1 / 2$ clinical trial. In India, Premas Biotech also developing a triple antigen virus-like particle (VLP) and completed animal trials. The DNA, peptide, and Adeno-associated virus vector vaccines and the immune response generations were shown in Figure 4.

\subsubsection{Advantages}

The vaccines developed on this platform has a major advantage of generating a strong immune response even without any adjuvant and can also trigger $\mathrm{T}$ cell-mediated responses. Its production takes very less time $\sim 3-12$ weeks without the threat of a reversal of virulence (Urakami et al., 2017; Wallis et al., 2019).

\subsubsection{Concerns}

Require cold chain transfer, less stable (Wallis et al., 2019).

\section{Route of Administration}

We discussed above the different types of vaccine production platforms through which SARS- CoV-2 vaccines are being developed. Also, the route of administration plays a role in SARS CoV2, if we consider the pathophysiology. The data from earlier Corona viral (SARS \& MERS) vaccines administered through nasal route gave promising results, favoring this route of administration (Marasini \& Kaminskas, 2019). The intranasal inoculation of recombinant Adeno associated Viral vector (rAAV) encoding receptor binding( RBD) of spike protein-induced strong mucosal immune responses and provided long-term protection against SARS-CoV infection in mouse (Du et al., 2008). Other research groups reported the successful production of neutralizing serum antibodies in monkeys vaccinated (BHPIV3/SARS-S) through the respiratory tract (Bisht et al., 2004; Bukreyev et al., 2004). The brief outline of intranasal vaccine administration and the mucosal immune response is shown in Figure 5. Few companies are working in this route of administration and reported promising results. Bharat Biotech, India and Flu-Gen, USA has developed a vaccine called CoroFlu as a part of an international collaboration of virologists, which is administered through intranasal route, entered phase 2 clinical trials. This is developed by inserting SARS-CoV-2 spike gene sequences into M2SR (which is a self-limiting version of influenza virus), can induce immune responses against both influenza and $\mathrm{CoV}$ because it also expresses hemagglutinin protein of influenza virus (Pharmatutor). Apart from this, four more nasal vaccines has been developed by the University of Virginia (Protein subunit based); FBRI SRC VB vector, Rospotrebnadzor koltsovo, Biocad/ IEM (Both are replicating viralbased) and eThe RNA (RNA based) and these are in preclinical phase.

The generation of immune response by the different types of vaccines production platforms such as Adenovirus based vaccines, DNA, peptide vaccines shown in the figure $3 \mathrm{a}$. Further, if we introduce these vaccines in the nasal route how they generate the immune response and protect the immunized individual shown in figure $3 \mathrm{~b}$. 


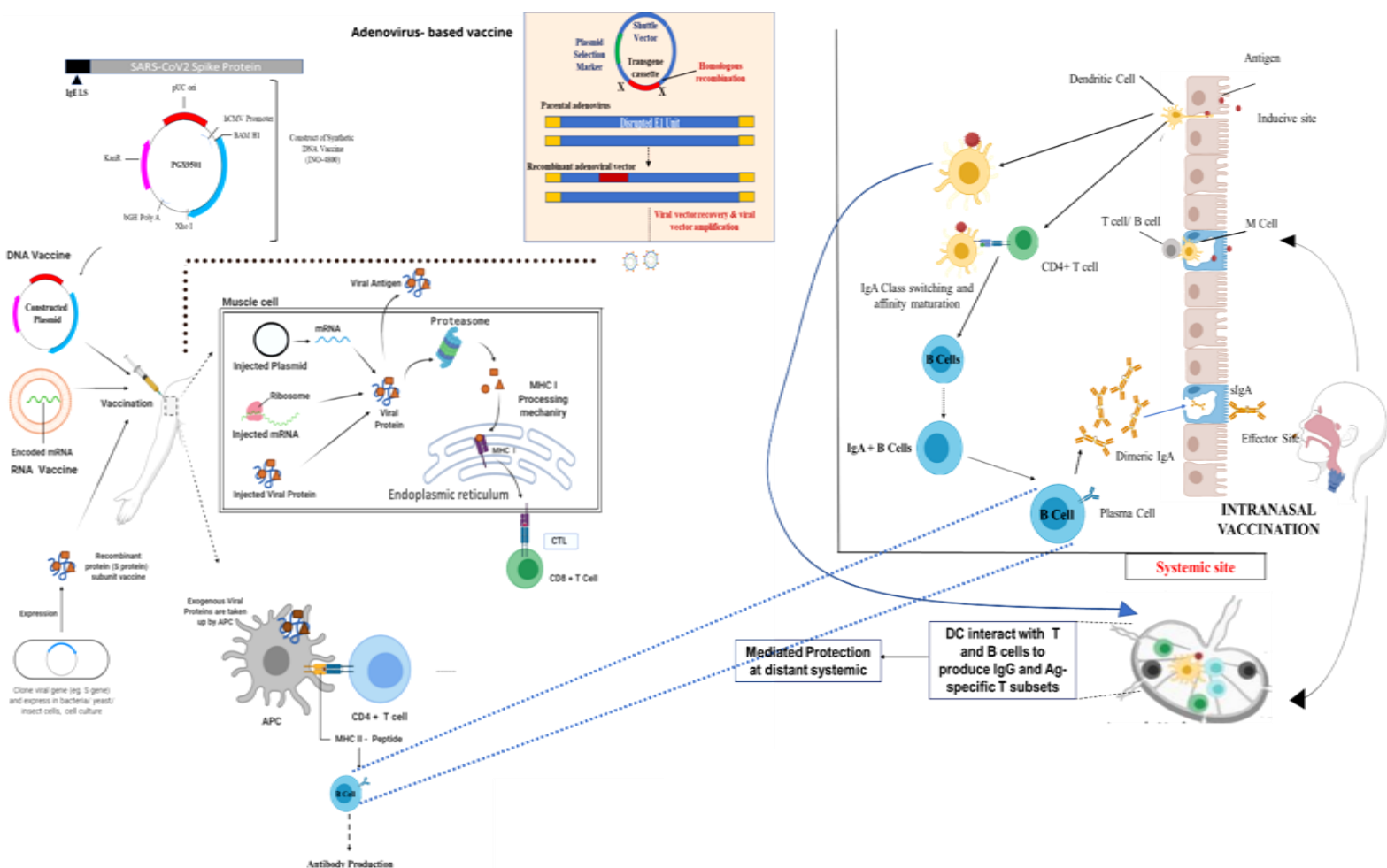

Figure 3 Schematic representation of DNA/RNA/Peptide/Adenoviral vector-based vaccines and the generation of immune response through intramuscular/intranasal route of administration

(A)

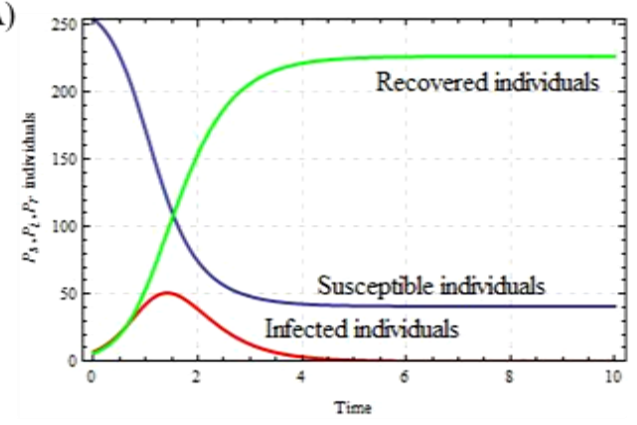

(C)

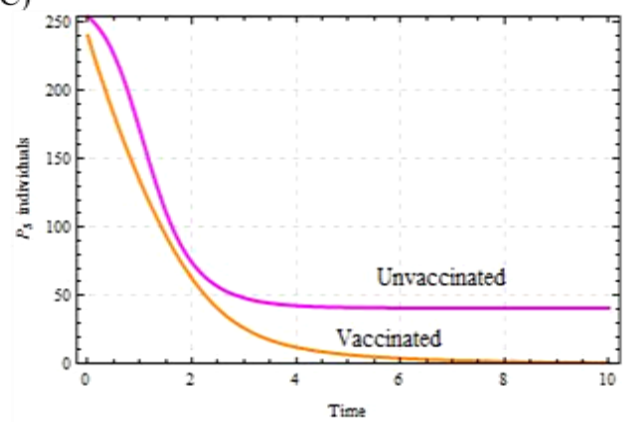

(B)

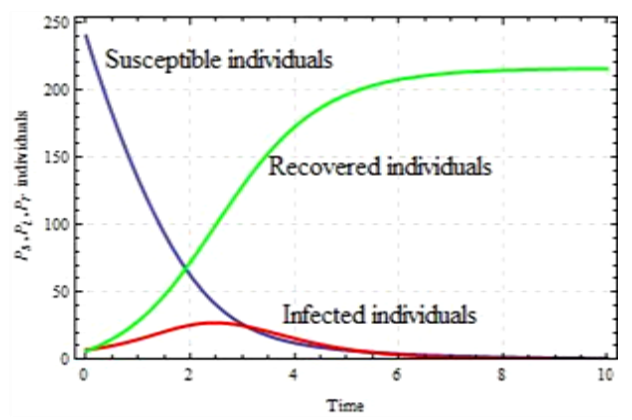

(D)

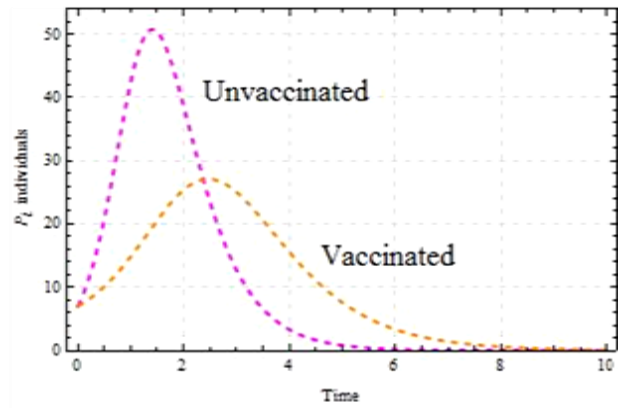

Figure 4 The significance of Vaccination in controlling the Pandemics among the human population (A) Number of susceptible, infectious and recovered individuals for unvaccinated model. (B) Number of susceptible, infectious and recovered individuals for vaccinated model. (C) Number of susceptible for unvaccinated and vaccinated model. (D) Number of infectious for unvaccinated and vaccinated model.

Journal of Experimental Biology and Agricultural Sciences http://www.jebas.org 
10 Jan, 2020

SARS-COV-2

Sequences published

1

\section{Timeline for SARS-CoV-2 Vaccine Development}

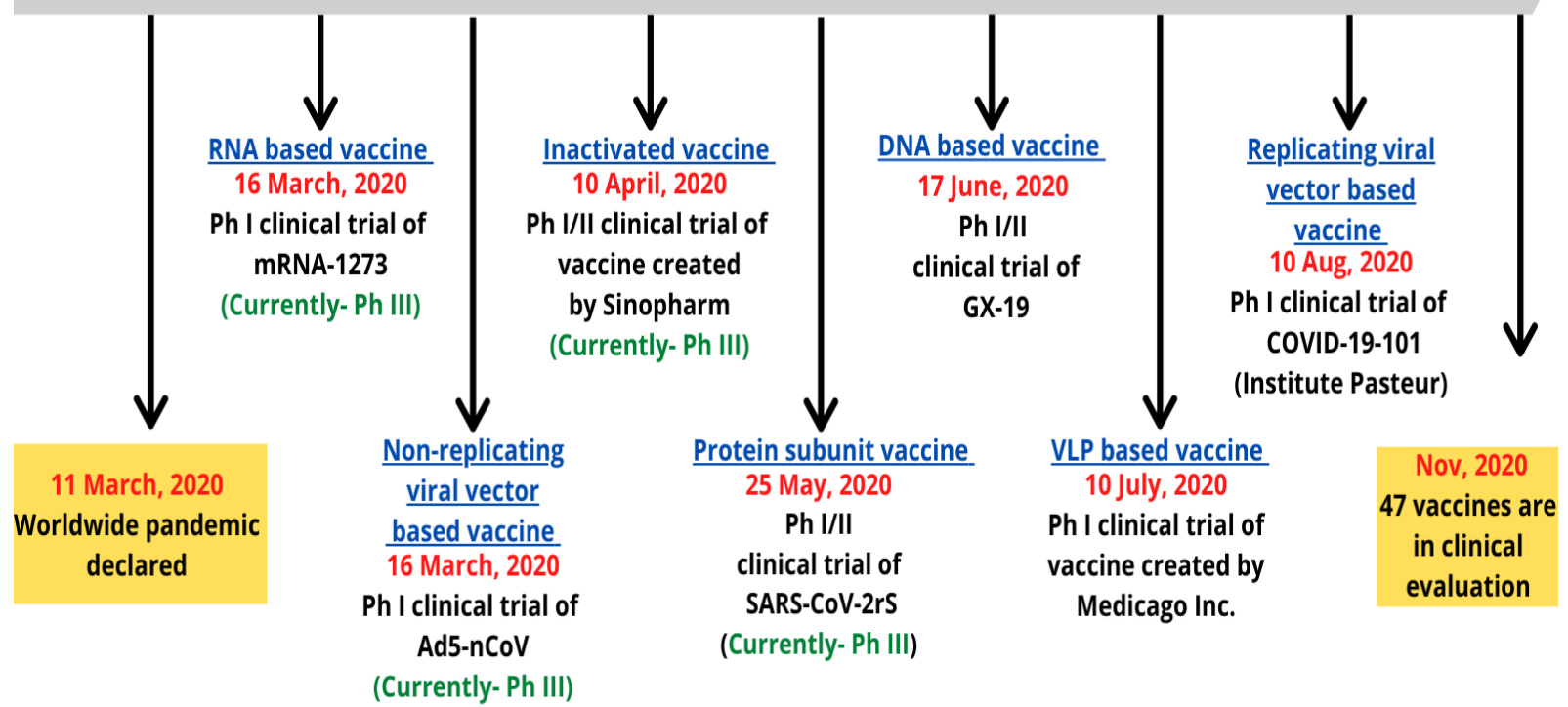

\section{Estimated Study Completion date of Phase III Clinical Trials}

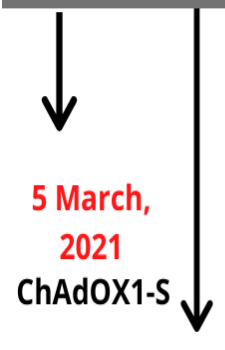

10 March, 2021

Ad26COvS1

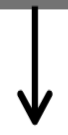

10 April, 2021

rAd26S+rAd5-S
1 December, 2021

Inactivated vaccine

by Sinopharm
October, 2021 Inactivated vaccine

by Sinovac

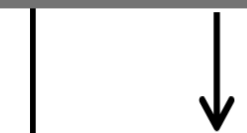

11 December, 2022

BNT162b1/2

30 December, 2022
27 October, 2022

mRNA 1273

Adjuvant

Figure 5 The Proposed time line for SARS- CoV-2 Vaccines development (Time lines of different SARS- CoV-2 vaccines entering in clinical trials and their expected use for human use)

Journal of Experimental Biology and Agricultural Sciences http://www.jebas.org 
Table 2: Advantages and Limitations of different vaccine platform employed for SARS-CoV-2 vaccine production

\begin{tabular}{|c|c|c|c|c|}
\hline $\begin{array}{l}\text { S. } \\
\text { No. }\end{array}$ & $\begin{array}{l}\text { Vaccine } \\
\text { Platform }\end{array}$ & Advantages & Limitations & References \\
\hline 1 & $\begin{array}{c}\text { RNA } \\
\text { vaccines }\end{array}$ & $\begin{array}{l}\text { Easy to construct directly from desired animal's } \\
\text { genetic sequence making production highly } \\
\text { flexible, no risk of host DNA integration }\end{array}$ & $\begin{array}{l}\text { Transfection efficacy of RNA based } \\
\text { vaccines is around ten -fold lower } \\
\text { than viral vector, toxicity due to } \\
\text { intrinsic inflammatory activity, } \\
\text { Shorthalf life of m RNA, lower } \\
\text { protein translation and as these } \\
\text { vaccines are fragile thus for transport } \\
\text { and storage its need an uninterrupted } \\
\text { cold chain process. }\end{array}$ & $\begin{array}{l}\text { Conforti et al., 2020; Wang } \\
\text { et al., } 2020\end{array}$ \\
\hline 2 & $\begin{array}{c}\text { DNA } \\
\text { vaccines }\end{array}$ & $\begin{array}{l}\text { Good biocompatibility, long shelf life and } \\
\text { stability, as manufacturing is completely cell } \\
\text { free thus bypassing the need for BSL } 2 \text { and } \\
\text { making its large scale production process easy, } \\
\text { cost-effective, and fast }\end{array}$ & $\begin{array}{l}\text { Possibility of the DNA integration in } \\
\text { the host genome, require several } \\
\text { prime-boost regimes and lower } \\
\text { generation of immunogenicity, }\end{array}$ & $\begin{array}{l}\text { Hobernik\& Bros, 2018; } \\
\text { Koirala et al., 2020; } \\
\text { Manam et al., 2000; Al- } \\
\text { Kassmy et al., } 2020\end{array}$ \\
\hline 3 & $\begin{array}{l}\text { viral } \\
\text { vector } \\
\text { vaccines }\end{array}$ & $\begin{array}{l}\text { viral vector platform has an extensive record of } \\
\text { safety, these are genetically and physically } \\
\text { stable, no risk of integration, non replicating } \\
\text { viral vectors are being used for gene therapy } \\
\text { from many years, the transfection efficacy is } \\
\text { high because viral vector mimic the natural } \\
\text { process of infection, viral vector especially } \\
\text { adenovirus based has been determined to have } \\
\text { multiple serotypes and these are highly } \\
\text { immunogenic resulting to the high performance } \\
\text { as vaccine delivery vehicles, } \\
\text { Advantages of Modified vaccinia virus Ankara } \\
\text { (MVA) as a viral vector: it does not require an } \\
\text { established cold chain, manufacturing is } \\
\text { inexpensive, and it can accommodate large } \\
\text { gene inserts and has been seen to elict a strong } \\
\text { immunological response. Vaccines based on } \\
\text { replicating viral vector platform are safe as an } \\
\text { oral vaccine as well as for intranasal } \\
\text { administration, }\end{array}$ & $\begin{array}{l}\text { High doses of non-replicating viral } \\
\text { vetor based vaccines are needed, } \\
\text { During production chances of } \\
\text { recombination, Previous exposure to } \\
\text { the virus causes pre-existing } \\
\text { immunity against vector as a result it } \\
\text { leads to the neutralizing antibody } \\
\text { production which reduces efficacy of } \\
\text { vaccine }\end{array}$ & $\begin{array}{l}\text { Markusic et al., 2017; } \\
\text { Wang et al., 2020; Ertl, } \\
\text { 2016; Afrough et al., 2019; } \\
\text { Guroff, } 2007\end{array}$ \\
\hline 4 & $\begin{array}{l}\text { Protein } \\
\text { Subunit } \\
\text { Vaccines }\end{array}$ & $\begin{array}{l}\text { Easy to produce, combine many pathogen } \\
\text { epitopes in a single vaccine candidate, safe } \\
\text { and distribute without any issue of cold chain }\end{array}$ & 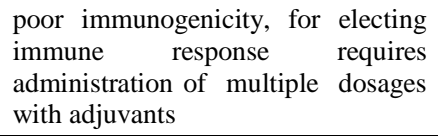 & $\begin{array}{l}\text { Afrough et al., 2019; Wang } \\
\text { et al., } 2020\end{array}$ \\
\hline 5 & $\begin{array}{l}\text { Whole } \\
\text { virus } \\
\text { inactivate } \\
\text { d or killed }\end{array}$ & $\begin{array}{l}\text { This vaccine production strategy has been using } \\
\text { for many years as a successful vaccination } \\
\text { platform formulation is simple }\end{array}$ & $\begin{array}{l}\text { limited and short duration of the } \\
\text { vaccination response, risk of hazard } \\
\text { to environment and person involved } \\
\text { in vaccine manufacturing because its } \\
\text { manufacture involves infectious } \\
\text { agent's culture in large amount and } \\
\text { the culture medium may contain } \\
\text { unwanted protein that can be allergic } \\
\text { and also affect its immunogenicity }\end{array}$ & $\begin{array}{l}\text { Afrough et al., 2019; } \\
\text { Francis, } 2017\end{array}$ \\
\hline 6 & $\begin{array}{l}\text { Live } \\
\text { attenuated } \\
\text { vaccines } \\
\text { (LAV) } \\
\text { vaccines }\end{array}$ & $\begin{array}{l}\text { Vaccines based on this platform (LAV) are } \\
\text { found to employ wide cross- protection, these } \\
\text { are immunologically highly efficient and it can } \\
\text { be scale -up for mass production. }\end{array}$ & $\begin{array}{l}\text { During distribution cold chain } \\
\text { should be maintained and require } \\
\text { extensive safety testing because } \\
\text { there is a risk that it can revert to full } \\
\text { virulence. }\end{array}$ & $\begin{array}{l}\text { Shin et al., 2020; Amanat } \\
\text { \& Krammer, 2020; Francis, } \\
\text { 2017; Begum et al., 2020; } \\
\text { Frederiksen et al., 2020 }\end{array}$ \\
\hline 7 & $\begin{array}{l}\text { Virus-like } \\
\text { particle } \\
\text { (VLP) } \\
\text { based } \\
\text { Vaccines }\end{array}$ & $\begin{array}{l}\text { Generate a strong immune response even } \\
\text { without any adjuvant and can also trigger } T \\
\text { cell- mediated responses and its production } \\
\text { takes very less time } \sim 3-12 \text { weeks without the } \\
\text { threat of reversal of virulence }\end{array}$ & $\begin{array}{l}\text { Require cold chain transfer, less } \\
\text { stable }\end{array}$ & $\begin{array}{l}\text { Urakami et al., 2017; } \\
\text { Wallis et al., } 2019\end{array}$ \\
\hline
\end{tabular}




\section{Challenges for developing SARS- CoV-2 Vaccines}

- Currently, many vaccine candidates for SARS-CoV-2 are in clinical trials and some of them are on the verge of completion of phase III clinical trials. However, few challenges still need to be addressed, the most challenge faced by the vaccine specialists are the observation of waning of antibody response in SARSCoV-2 patients, the same was also observed in the case of SARS and MERS- CoV's and also the nasal virus shedding which can be prevented by boosting mucosal immunity but as we knew that mucosal immunity is generally short-lived thus it requires multiple booster vaccinations (Begum et al., 2020; Wu et al. (2007), shown waning of antibody response against other coronaviruses within 12-52 weeks from the onset of symptoms. In their 3 years of study, found that $\geq 3$ years after the onset of symptoms, SARS-CoV antibodies had decreased (Wu et al., 2007) and 45 weeks were the estimated period of protective immunity, observed in the case of $\mathrm{HCoV}-\mathrm{OC} 43$ and $\mathrm{HCoV}$ HKU1 (ECDC, 2020). So it's the biggest challenge if we administer the vaccine against SARS-CoV-2, how long it protects the individual, and will these vaccines able to prevent both deaths as well as nasal shedding of virus? Shall we go for repetitive vaccines as we have seen in flu vaccines, need to be understood.

- Another challenge in SARS- CoV-2 infections was that most of the affected individuals are above the age of 50 years, the immune status of these individuals may be at the beginning of immune senescence (Sambhara \& McElhaney, 2009). So, the developed vaccines should be successful in the elderly as well as children below 10years. The side effects observed in the vaccinated people had experienced some side effects such as muscle pain, joints pain, fever, etc. Thus it is still a question that whether these vaccines will be safe for the one who needed it most such as people above 70 years, people with some medical conditions such as diabetic patients, immunocompromised patients and pregnant as well as lactating women. Apart from these questions one more question is needs to be answered that which vaccine candidate will be suitable for pregnant women? (Heath et al., 2020).

- Although it has been observed that children are less affected by COVID-19, they likely play a role in the transmission of SARSCoV-2 (Kao et al., 2020) thus children should also be vaccinated so that they can be protected and not able to infect adults. But, most of the vaccine trials were done on the age group 18-59 (WHO), this group is also included to get the overall efficacy of the vaccine. The results from the previous studies on the vaccine against Respiratory Syncytial Virus (RSV) in children not given promising results. Many vaccinated children developed serious illness when they were infected with a natural virus and two toddlers even died due to the severe damage to their lung tissue, a researcher Hotez observed the same pattern of immune cells attacking the lung tissue of SARS vaccinated animal (vaccine expressed whole S protein) as in case of RSV vaccines trails on children, however, his team overcame this drawback by developing RBD based vaccine (Acosta et al., 2015; Peeples, 2020), but it still raised the question that whether COVID-19 vaccines will be safe for children or not?.

- Although 47 candidate vaccines are in the clinical phase of evaluation, still there are 156 vaccines currently evaluating in preclinical phase, the major concern in testing the safety and efficacy of vaccines in animal model is the finding of suitable animal model which can properly mimic human COVID-19 infection as well as can reflects similar immune response (Begum et al., 2020; Hartung \& Aktas, 2020). While the major concern in clinical phase of evaluation is the risk of volunteer health, participating in vaccine clinical trials, as the SARS-CoV2 is also able to infect human brain, thus volunteers can suffer from chronic infection leading to neurogenerative disease (Hartung \& Aktas, 2020).

- As the human population has faced three pandemics caused by Corona Viruses (CoVs), within less than 20 years thus it made it more clear that the human race can face another $\mathrm{CoVs}$ pandemic in the future. Therefore, one more important point we should consider that whether these vaccines against current versions of coronavirus, will also able to protect from the new version of coronaviruses, that likely to emerge in the future or not?

- Effectiveness of vaccines are another major challenge because no vaccine is $100 \%$ effective, the biggest example is the influenza vaccine having efficacy around $19-60 \%$ (according to CDC report), raising the question of the effectiveness of SARSCoV-2 vaccine candidates, although vaccine having more than $50 \%$ efficacy would be better and will able to reduce COVID-19 incidence in individuals that have been vaccinated (Hartung \& Aktas, 2020; Krause et al., 2020).

- Last but not the least, even after the successful development of vaccines against SARS-CoV-2, vaccine hesitancy will also be another challenge. In a study conducted in Israeli population, it has been found that there are both positive as well as negative predictors for vaccination such as healthcare employees especially those caring for COVID-19 patients, physician and male sex are found as positive predictors who are more likely to accept future SARS-CoV-2 vaccines while nurses and parenthood were found as negative predictors (Dror et al., 2020).

- Considering the pathophysiology of COVID-19, the intranasal route of administration of vaccine also needs to be explored. Most of the vaccines are administered parenterally/ orally, the dosage optimization and the suitable adjuvants were standardized. Further, the parenterally administered vaccines priming the lymphocytes and homing such lymphocytes to the lungs and gastrointestinal tract and eliciting the $\operatorname{IgA}$ antibody response gives an edge to this route, however, the efficacy of 
nasal route also explored for COVID-19 vaccines. The timeline for the SARS coV2 vaccines preparation beginnings, their Clinical trials, and their availability to humans were depicted in Figure 4.

\section{Basic Mathematical model explains the importance of Vaccination on SARS-CoV2}

Enthusiastic Mathematicians generated Mathematical models to track the spread of the virus and to mobilize the speed of innovative diagnostics and are working on several vaccines to protect against COVID-19. A statistical approach is given by Nesteruk (2020) on this epidemic, and this model approach has been a breakthrough in modeling disease control as used by several authors (Brauer et al., 2012; Oduwole \& Kimbir, 2018; Ming et al., 2020). Complicated mathematical models are necessary which need many efforts for unknown parameters identification and calculations for long time predictions. The following models are useful for the dynamics of an epidemic to estimate the number of infected persons. If $P_{S}$ is the number of susceptible persons, $P_{i}$ is the number of infected persons, $P_{r}$ is the number of removed persons, $P_{v}$ is the number of vaccinated persons, and ' $\mathrm{t}$ ' is the time of outbreak of epidemic the rate of change of these three types of equations can be modelled by using law of natural growth /decay as follows. In the modelled equations $\beta$ and $\alpha$ are considered as infected and immunization rates of the population.

$\frac{d P_{s}}{d t}=-\beta P_{S} P_{i}$

$\frac{d P_{i}}{d t}=\beta P_{S} P_{i}-\alpha P_{i}$

$\frac{d P_{r}}{d t}=\alpha P_{i}$

From Equations (1) to (3) it is observed that

$$
\begin{aligned}
& \frac{d P s}{d t}+\frac{d P i}{d t}+\frac{d P r}{d t}=0 \\
& \frac{d}{d t}\left(P_{s}+P_{i}+P_{r}\right)=0 \\
& P_{s}+P_{i}+P_{r}=\mathrm{N}
\end{aligned}
$$

Where $\mathrm{N}$ is the constant and can be considered as the number of susceptible persons before the outbreak of an epidemic. The following can be considered as the initial conditions for the set of equations (1 -3).

$$
\left\{\begin{array}{l}
P_{i}=1 \\
P_{r}=0 \\
P_{S}=N-1
\end{array} \text { at } \mathrm{t}=0\right.
$$

From equations (1-2)

$\frac{d P_{i}}{d P_{s}}=\frac{\gamma}{P_{S}}-1$ where $\left(\gamma=\frac{\beta}{\alpha}\right)$

$P_{i}=\gamma \ln P_{s}-P_{s}+N-\gamma \ln (N-1)$
This number of infected persons $P_{i}$ is maximum when susceptible person's number, $P_{S}$ is equal to $\gamma$. By considering the statistical data from particular area by using equation (7) we can estimate the number of infected persons and can go for the necessary actions.

\subsection{Vaccination model}

If we introduce vaccination in the above model, it will become

$\frac{d P_{s}}{d t}=-\beta P_{S} P_{i}-\delta P_{s}$

$\frac{d P_{v}}{d t}=\delta P_{s}-\sigma \beta P_{v} P_{i}$

$\frac{d P_{i}}{d t}=\beta P_{s} P_{i}+\sigma \beta P_{v} P_{i}-\alpha P_{i}$

$\frac{d P_{r}}{d t}=\alpha P_{i}$

where susceptible are reduced by a factor $\sigma$ at a rate $\delta$.

The significance of vaccination in any epidemic is shown in fig 4 by the above mathematical modelling.

\section{Conclusions}

Though we don't have effective vaccines for earlier Corona viral outbreaks such as SARS-CoV and MERS-CoV, the structural studies about the said viruses and the vaccine production platforms tried for these viral vaccines greatly benefitted in the road map of SARS- CoV-2 Vaccine preparations.

First time the DNA and RNA-based vaccines were entered in clinical trials for SARS-CoV-2, showing impressive results in the study groups. However, how these vaccines will work on the large human populations of different ethnic groups need to be analyzed.

The effectiveness of the vaccines produced for SARS $-\mathrm{CoV}-2$ were generally based on the neutralizing capacity of antibodies in in-vitro. Further studies are going on to check the efficacy of these vaccines in invivo, as we learned that waning of the antibody response against SARS CoV-2 in the COVID-19 recovered individuals. This gives a question mark that how much time the generated antibodies present in the vaccinated individuals, whether they confer long term immunity or not need to be analyzed.

It is early to say which vaccine produced by which vaccine production platform gives an effective vaccine for SARS-CoV-2, because, currently we don't have an animal model that can mimic human infection. Most of the results obtained are from non-human primates, ferrets and genetically engineered mice. Based on such experimental results directly going for clinical trials may pose deleterious effects.

Though, there are many if and buts for almost all vaccines of SARS-CoV-2, certainly would overcome these hurdles and bring 
the vaccines in record time. Generally, the vaccine preparation for any disease is a long time process taking enough of 10-15 years, still, we don't have any vaccines such as AIDS and tuberculosis, the global efforts of vaccine preparation for SARS CoV-2 may change the paradigm shift in vaccine preparation.

After the success of convalescent plasma therapy in stage III COVID-19 patients, the pharmaceutical companies looking for the development of passive immunity in the individuals which can give short-time protection for the SARS-CoV-2 infection. The trials for these recombinant monoclonal antibodies are under progress.

By summing up the SARS CoV-2 vaccine landscape would certainly change the paradigm of vaccine production time and strategies in the coming future

\section{Conflict of Interest}

Authors declare no conflict of Interest

\section{Acknowledgements}

Authors would like to acknowledge the fellowship grants by ICMR, New Delhi (Mr. Abhishek Pandeya, ICMR -SRF Award no: 45/28/2018/IMM/BMS) DBT Project No BT/PR14198/MED/29/980/2015 (Mr. Anup Mishra, DBT-SRF) \& NFST Fellowship, Ministry of Tribal Affairs, Govt of India (Mr Raj Kumar Khalko; Award no: 201819-NFST-JHA-02141)

\section{References}

Acosta PL, Caballero MT, Polack FP (2016) Brief history and characterization of enhanced respiratory syncytial virus disease. Clinical and Vaccine Immunology 23(3): 189-195.

Afrough B, Dowall S, Hewson R ( 2019). Emerging viruses and current strategies for vaccine intervention. The Journal of Translational Immunology 196: 157-166.

Al-Kassmy J, Pedersen J, Kobinger G (2020) Vaccine Candidates against Coronavirus Infections. Where Does COVID-19 Stand?. Viruses 12(8):E861.

Amanat F, Krammer F (2020) SARS-CoV-2 vaccines: status report. Immunity 52(4): 583-589.

Arumugam VA, Thangavelu S, Fathah Z, et al. (2020) COVID-19 and the World with Co-Morbidities of Heart Disease, Hypertension and Diabetes. Journal of Pure and Applied Microbiology 14(3):1623-1638. doi: 10.22207/JPAM.14.3.01.

Begum J, Mir NA, Dev K, Buyamayum B, Wani MY, Raza M (2020) Challenges and prospects of COVID-19 vaccine development based on the progress made in SARS and MERS vaccine development. Transboundary and Emerging Diseases https://doi.org/10.1111/tbed.13804.

Bisht H, Roberts A, Vogel L, Bukreyev A, Collins PL, Murphy BR, Subbarao K, Moss B (2004) Severe acute respiratory syndrome coronavirus spike protein expressed by attenuated vaccinia virus protectively immunizes mice. Proceedings of the National Academy of Sciences 101(17): 6641-6646.

Brauer F, Castillo-Chavez C, Castillo-Chavez C (2012) Mathematical models in population biology and epidemiology (Vol. 2). New York: Springer Pp. 508.

Bukreyev A, Lamirande EW, Buchholz UJ, Vogel LN, Elkins WR, St Claire M, Murphy BR, Subbarao K, Collins PL (2004) Mucosal immunisation of African green monkeys (Cercopithecus aethiops) with an attenuated parainfluenza virus expressing the SARS coronavirus spike protein for the prevention of SARS. The Lancet, 363(9427): 2122-2127.

Cai Y, Zhang J, Xiao T, Peng H, Sterling SM, Jr RMW, Rawson S, Rits-Volloch S, Chen B (2020) Distinct conformational states of SARS-CoV-2 spike protein. Science 369 (6511): 1586-1592.

Calina D, Hartung T, Docea AO, et al. (2020) COVID-19 vaccines: ethical framework concerning human challenge studies.

Daru 1-6. doi: 10.1007/s40199-020-00371-8.

Callaway E (2020) Fast-track coronavirus vaccine draws outrage over safety. Nature 584(7821):334-335.

Carlson R (2020) CVnCoV SARS-CoV-2 vaccine. Precision vaccination.

https://www.precisionvaccinations.com/vaccines/cvncov-sars-cov2-vaccine.: Accessed on: 29 August 2020.

Conforti A, Marra E, Roscilli G, Palombo F (2020) Are Genetic Vaccines the right weapon against COVID-19. Molecular therapy 28: $1555-1556$

Corbett KS, Flynn B, Foulds KE, Francica JR, Boyoglu-Barnum S, Werner AP, Nagata BM et al (2020) Evaluation of the mRNA1273 vaccine against SARS-CoV-2 in nonhuman primates. New England Journal of Medicine 383:1544-1555.

COVID- 19 Vaccine development using new, fast-growing tobacco plant technology., Crop Biotech Update. (2020) ISAAAhttp://www.isaaa.org/kc/cropbiotechupdate/article/default.a sp?ID=18081 accessed on 22 April 2020 .

Dhama K, Khan S, Tiwari R, Sircar S, Bhat S, Malik YS, Singh KP, Chaicumpa W, Bonilla-Aldana DK, Rodriguez-Morales AJ (2020a) Coronavirus Disease 2019-COVID-19. Clinical 
Microbiology Reviews 33(4):e00028-20.

10.1128/CMR.00028-20.

Dhama K, Natesan S, Yatoo MI, Patel SK, Tiwari R, Saxena SK, Harapan H (2020d) Plant-based vaccines and antibodies to combat COVID-19: Current status and prospects. Human Vaccines and Immunotherapeutics

https://doi.org/10.1080/21645515.2020.1842034.

Dhama K, Patel SK, Sharun K, Pathak M, Tiwari R, Yatoo MI, Malik YS, Sah R, Rabaan AA, Panwar PK, Singh KP, Michalak I, Chaicumpa W, Martinez-Pulgarin DF, Bonilla-Aldana DK, Rodriguez-Morales AJ (2020b) SARS-CoV-2 jumping the species barrier: Zoonotic lessons from SARS, MERS and recent advances to combat this pandemic virus. Travel Medicine and Infectious Disease 37:101830. doi: 10.1016/j.tmaid.2020.101830.

Dhama K, Sharun K, Tiwari R, Dadar M, Malik YS, Singh KP, Chaicumpa W (2020c) COVID-19, an emerging coronavirus infection: advances and prospects in designing and developing vaccines, immunotherapeutics, and therapeutics. Human Vaccines and Immunotherapeutics 16(12): doi 10.1080/21645515.2020.1735227.

DiazGranados CA, Dunning AJ, Jordanov E, Landolfi V, Denis M, Talbot HK (2013) High-dose trivalent influenza vaccine compared to standard dose vaccine in elderly adults: safety, immunogenicity and relative efficacy during the 2009-2010 season. Vaccine 31: 861-86610.1016/j.vaccine.2012.12.013

Dror AA, Eisenbach N, Taiber S, et al. (2020) Vaccine hesitancy: the next challenge in the fight against COVID-19 (published online ahead of print, 2020 Aug 12). European Journal of Epidemiology 35(8): 775-779.

Du L, Zhao G, Lin Y, Sui H, ChanC., Ma S, et al. (2008) Intranasal vaccination of recombinant adeno-associated virus encoding receptor-binding domain of severe acute respiratory syndrome coronavirus (SARS-CoV) spike protein induces strong mucosal immune responses and provides long-term protection against SARSCoV infection. The Journal of Immunology 180(2): 948-956.

ECDC (European Center for disease prevention and control) (2020) Immune response and immunity to SARS-CoV-2. Available at https://www.ecdc.europa.eu/en/covid-19/latestevidence/immune-responses accessed on: 29 August 2020.

Ertl HCJ (2016) Viral vectors as vaccine carriers. Current Opinion in Virology 17: 1-8.

Francis MJ (2017) Recent advances in vaccine technology. The veterinary clinics of north Ameria, small animal practice 48(2): 231-241. oi: Frederiksen LSF, Zhang Y, Foged C, Thakur A (2020) The Long Road Toward COVID-19 Herd Immunity: Vaccine Platform Technologies and Mass Immunization Strategies. Frontiers in Immunology 11:1817.

Funk CD, Laferriere C, Ardakani A (2020) A snapshot of the global race for vaccines targeting SARS-CoV-2 and the COVID19 pandemic. Frontiers in Pharmacology 11(937): 1-17.

Guroff MR (2007) Replication and non-replication viral vectors for vaccine development. Current Opinion in Biotechnology 18: 546556.

Hartung H, Aktas O (2020) COVID-19 and management of neuroimmunological disorders. Nature Reviews Neurology 16: 347-348. https://doi.org/10.1038/s41582-020-03689.

Heath PT, Le Doare K, Khalil A (2020) Inclusion of pregnant women in COVID-19 vaccine development. Lancet Infectious Diseases 20(9):1007-1008.

Hobernik D, Bros M (2018). DNA vaccines-how far from clinical use? International Journal of Molecular Sciences 19(11): 3605.

Infovac (July 24, 2020) Coronavirus (COVID-19). Available at https://www.infovac.ch/fr: Accessed on 29 August 2020.

Jackson LA, Anderson EJ, Rouphael NG, et al. (2020) An mRNA Vaccine against SARS-CoV-2 - Preliminary Report. New England Journal of Medicine, 383:1920-1931. DOI: 10.1056/NEJMoa2022483.

Jefferys R (2020) COVID-19 vaccines. Available at https://www.infovac.ch/fr/Jeffreys Accessed on: 29 August 2020.

Kao CM, Orenstein WA, Anderson EJ (2020) The Importance of Advancing SARS-CoV-2 Vaccines in Children. Clinical Infectious Diseases 712: 1-4.

Kaur SP, Gupta V (2020) COVID-19 Vaccine: A comprehensive status report. Virus Research 288: 198114.

Khan T (2020) Genexine consortium develops COVID-19 vaccine for human testing. Available at https://pharmashots.com/pressreleases/korean-biotech-firm-genexines-covid-19-

deoxyribonucleic-acid-vaccine-pipeline-gx-19-is-ready-forclinical-testing-as-soon-as-it-applies-to-the-drug-ministry-forhuman-testing/ access on $25^{\text {th }}$ October 2020.

Khuroo MS, Khuroo M, Khuroo MS, Sofi AA, Khuroo NS (2020) COVID-19 Vaccines: A Race Against Time in the Middle of Death and Devastation! Journal of Clinical and Experimental Hepatology https://doi.org/10.1016/j.jceh.2020.06.003. 
King A (2020) Explainer: how is the vaccine pipeline for Covid-19 looking? 30 June 2020.; Chemistry world, Available at https://www.chemistryworld.com/news/explainer-how-is-thevaccine-pipeline-for-covid-19 looking/4012068.article accessed on: 29 August 2020.

Koirala A, Joo YJ, Khatami A, Chiu C, Britton N (2020) Vaccines for COVID-19: the current state of play. Paediatric Respiratory Reviews 35: 43-49.

Krause P, Fleming TR, Longini I, Henao-Restrepo AM, Peto R (2020) World Health Organization Solidarity Vaccines Trial Expert Group. COVID-19 vaccine trials should seek worthwhile efficacy. Lancet 396(10253): 741-743.

Lan J, Ge J, Yu J, Shan S, Zhou H, Fan S, Zhnag Q, Shi X, Wang Q, Zhang L, Wang X (2020) Structure of the SARS-CoV-2 spike receptor-binding domain bound to the ACE2 receptor. Nature 581(7807): 215-220.

Lauxmann MA, Santucci NE, Autran-Gomez AM (2020) The SARS-CoV-2 Coronavirus and the COVID-19 Outbreak. International Brazilian Journal of Urology 46(1): 6-18.

Liu W, Tao ZW, Wang L, Yuan ML, Liu K, Zhou L, et al. (2020) Analysis of factors associated with disease outcomes in hospitalized patients with 2019 novel coronavirus disease. Chinese Medical Journal 133(9): 1032-1038.

Manam S, Ledwith BJ, Barnum AB, Troilo PJ, Pauley CJ, Harper LB, Pacchione SJ, et al. (2000) Plasmid DNA vaccines: tissue distribution and effects of DNA sequence, adjuvants and delivery method on integration into host DNA. Intervirology 43(4-6): 273-281.

Marasini N, Kaminskas LM (2019) Subunit-based mucosal vaccine delivery systems for pulmonary delivery-Are they feasible? Drug Development and Industrial Pharmacy 45(6): 882-894.

Markusic DM, Nichols TC, Merricks EP, et al. (2017) Evaluation of engineered AAV capsids for hepatic factor IX gene transfer in murine and canine models. Journal of Translational Medicine 15: 94. https://doi.org/10.1186/s12967-017-1200-1Markusic\& Herzog 2016.

Michelozzi P, de'Donato F, Scortichini M, De Sario M, Noccioli F, Rossi P, Davoli M (2020) Mortality impacts of the coronavirus disease (COVID-19) outbreak by sex and age: rapid mortality surveillance system, Italy, 1 February to 18 April 2020. Eurosurveillance 25(19): 2000620.

Ming WK, Huang J, Zhang CJ (2020) Breaking down of healthcare system: Mathematical modelling for controlling the novel coronavirus (2019-nCoV) outbreak in Wuhan, China. bioRxiv, doi: https://doi.org/10.1101/2020.01.27.922443.
Murugan, (2020) How Indigenous is Bharat Biotech's New COVID-19 Vaccine, Covaxin? Available at https://science.thewire.in/health/how-indigenous-is-bharatbiotechs-new-covid-19-vaccine-covaxin; accessed on 29 August 2020.

Nesteruk I (2020) Statistics-based predictions of coronavirus epidemic spreading in mainland China. Innovative Biosystems and Bioengineering 4(1): 13-18.

Oduwole HK, Kimbir AR (2018) Modelling vertical transmission and the effect of Antiretroviral Therapy (ART) on the dynamics of HIV/AIDS in an age-structured population in Nigeria. Journal of Natural and Applied Sciences -Nasara Scientifique 7 (1): 51-78.

Peeples L (2020) News Feature: Avoiding pitfalls in the pursuit of a COVID-19 vaccine. Proceedings of the National Academy of Sciences 117(15): 8218-8221.

Rabaan AA, Al-Ahmed SH, Sah R, Al-Tawfiq JA, Al-Qaaneh AM, Al-Jamea LH, Woodman A, Al-Qahtani M, Haque S, Harapan H, Bonilla-Aldana DK, Kumar P, Dhama K, Rodriguez-Morales AJ (2020b) Recent advances in vaccine and immunotherapy for COVID-19. Human Vaccines and Immunotherapeutics 16(12): doi: $10.1080 / 21645515.2020 .1825896$.

Rabaan AA, Al-Ahmed SH, Sah R, Tiwari R, Yatoo MI, Patel SK, Pathak M, Malik YS, Dhama K, Singh KP, Bonilla-Aldana DK, Haque S, Martinez-Pulgarin DF, Rodriguez-Morales AJ, Leblebicioglu H (2020a) SARS-CoV-2/COVID-19 and advances in developing potential therapeutics and vaccines to counter this emerging pandemic. Annals of Clinical Microbiology and Antimicrobials 19(1):40. doi: 10.1186/s12941-020-00384-w.

Rauch S, Jasny E, Schmidt KE, Petsch B (2018) New vaccine technologies to combat outbreak situations. Frontiers in Immunology 9: 1963.

Rego GN, Nucci MP, Alves AH, Oliveira FA, Marti LC, Nucci LP, Mamani JB, Gamarra LF (2020) Current Clinical Trials Protocols and the Global Effort for Immunization against SARSCoV-2. Vaccines 8(3): 474.

Riedel S (2005) Edward Jenner and the history of smallpox and vaccination. Baylor University Medical Center Proceedings Taylor \& Francis 18 (1): 21-25.

Rodriguez-Morales AJ, Bonilla-Aldana DK, Tiwari R, Sah R, Rabaan AA, Dhama K (2020) COVID-19, an emerging coronavirus infection: current scenario and recent developments an overview. Journal of Pure and Applied Microbiology 14(1): 0512. https://doi.org/10.22207/JPAM.14.1.02 
Salvatori G, Luberto L, Maffei M, Aurisicchio L, Roscilli G, Palombo F, Marra E (2020) SARS-CoV-2 SPIKE PROTEIN: an optimal immunological target for vaccines. Journal of Translational Medicine 18: 1-3.

Sambhara S, McElhaney JE (2009) Immunosenescence and Influenza Vaccine Efficacy. In: Compans R, Orenstein W (Eds.) Vaccines for Pandemic Influenza. Current Topics in Microbiology and Immunology, Vol 333. Springer, Berlin, Heidelberg.

Shang J, wan Y, Luo C, Ye G, Geng Q, Auerbach A, Li F (2020) Cell entry mechanisms of SARS-CoV-2. PNAS 117(21): 1172711734 .

Shi R, Shan C, Duan X, Chen Z, Liu P, et al. (2020a) A human neutralizing antibody targets the receptor binding site of SARSCoV-2. Nature 584: 120-124.

Shi Y, Wang G, Cai XP, Deng JW, Zheng L, Zhu HH, Zheng M, Yang B, Chen Z (2020b) An overview of COVID-19. Journal of Zhejiang University-SCIENCE B (Biomedicine \& Biotechnology) 21(5): 343-360.

Shin MD, Shukla S, Chung YH, et al. (2020) COVID-19 vaccine development and a potential nanomaterial path forward. Nature Nanotechnology 15: 646-655. https://doi.org/10.1038/s41565-0200737-y.

Smith MJ, Hayward SA, Innes SM, Miller ASC (2020) Point-of-care lung ultrasound in patients with COVID-19-a narrative review. Anaesthesia 75 (8): 1096-1104.

Song, W, Gui M, Wang X, Xiang Ye (2020) Cryo-EM structure of the SARS coronavirus spike glycoprotein in complex with its host cell receptor ACE2. PLoS Pathology 14(8): 1-19.

Strugnell R, Zepp F, Cunningham A, Tantawichien T (2011) Vaccine antigens. Perspect Vaccinol 1(1): 61-88.

Tai W, He L, Zhang X, Pu J, Voronin D, Jiang S, Zhou Y, Du L (2020) Characterization of the receptor-binding domain (RBD) of 2019 novel coronavirus: implication for development of RBD protein as a viral attachment inhibitor and vaccine. Cellular \& Molecular Immunology 17(6): 613-620.

Tiwari R, Dhama K, Sharun K, Iqbal Yatoo M, Malik YS, Singh R, Michalak I, Sah R, Bonilla-Aldana DK, Rodriguez-Morales AJ
(2020) COVID-19: animals, veterinary and zoonotic links. Veterinary Quarterly 40(1):169-182. doi: 10.1080/01652176.2020.1766725.

Urakami A, Sakurai A, Ishikawa M, Yap ML, Flores-Garcia Y, Haseda Y, Aoshi T, Zavala FP, Rossmann MG, Kuno S, Ueno R, Akahata W (2017) Development of a novel virus-like particle vaccine platform that mimics the immature form of alphavirus. Clinical and Caccine Immunology 24(7): 1-14.

Vetter V, Denizer G, Friedland LR, Krishnan J, Shapiro M (2018) Understanding modern-day vaccines: what you need to know. Annals of medicine 50(2): 110-120.

Wallis J, Shenton DP, Carlisle RC (2019) Novel approaches for the design, delivery and administration of vaccine technologies. Clinical \& Experimental Immunology 196(2): 189204.

Walls AC, Park YJ, Tortorici MA, Wall A, McGuir AT, Veesler D (2020). Structure, Function, and Antigenicity of the SARS-CoV-2 Spike Glycoprotein. Cell 181(2): 281-292.

Wang J, Peng Y, Xu H, Cui Z, Williams RO (2020) The COVID19 vaccine race: Challenges and opportunities in vaccine formulation. AAPS pharmSciTech 21 (6): 225.

Wolff JA, Ludtke JJ, Acsadi G, Williams P, Jani A (1992) Longterm persistence of plasmid DNA and foreign gone expression in mouse muscle. Human Molecular Genetics 1(6): 363-369.

Wu L, Wang N, Chang Y, Tian X, Na D, Zhang L, Zheng L, Nan T, Wang L \& Liang G (2007) Duration of antibody responses after severe acute respiratory syndrome. Emerging Infectious Diseases 13(10): 1562-1564.

Yatoo MI, Hamid Z, Parray OR, Wani AH, Ul Haq A, Saxena A, Patel SK, Pathak M, Tiwari R, Malik YS, Sah R, Rabaan AA, Rodriguez Morales AJ, Dhama K. (2020) COVID-19 - Recent advancements in identifying novel vaccine candidates and current status of upcoming SARS-CoV-2 vaccines. Human Vaccines and Immunotherapeutics 1-14. doi: 10.1080/21645515.2020.1788310.

Zhu G, Zhu C, Zhu Y, Sun F (2020). Minireview of progress in the structural study of SARS-CoV-2 proteins. Current Research in Microbial Sciences 1: 53-61. 